\title{
Regulation of prostasin by aldosterone in the kidney
}

\author{
Takefumi Narikiyo, ${ }^{1}$ Kenichiro Kitamura, ${ }^{1}$ Masataka Adachi, ${ }^{1}$ Taku Miyoshi, ${ }^{1}$ \\ Kozo Iwashita, ${ }^{1}$ Naoki Shiraishi, ${ }^{1}$ Hiroshi Nonoguchi, ${ }^{1}$ Li-Mei Chen, ${ }^{2}$ Karl X. Chai, ${ }^{2}$ \\ Julie Chao, ${ }^{3}$ and Kimio Tomita ${ }^{1}$
}

${ }^{1}$ Third Department of Internal Medicine, Kumamoto University School of Medicine, Kumamoto, Japan
${ }^{2}$ Department of Molecular Biology and Microbiology, University of Central Florida, Orlando, Florida, USA
${ }^{3}$ Department of Biochemistry and Molecular Biology, Medical University of South Carolina, Charleston, South Carolina, USA
Address correspondence to: Kenichiro Kitamura, Third Department of Internal Medicine,
Kumamoto University School of Medicine, 1-1-1 Honjo, Kumamoto, Kumamoto 860-8556, Japan.
Phone: 81-96-373-5164; Fax: 81-96-366-8458; E-mail: ken@gpo.kumamoto-u.ac.jp.

Received for publication May 10, 2001, and accepted in revised form December 27, 2001.

Prostasin is a serine protease present in mammalian urine that increases the activity of the epithelial sodium channel $(\mathrm{ENaC})$ when the two are coexpressed in Xenopus oocytes. To determine if aldosterone, one of the principal regulators of urinary $\mathrm{Na}$ reabsorption by the distal nephron, affects prostasin expression, we examined prostasin mRNA and protein in a cultured mouse cortical collecting duct cell line (M-1), whole rats, and patients with primary aldosteronism. Aldosterone treatment of M-1 cells substantially increased prostasin expression and stimulated ${ }^{22} \mathrm{Na}$ uptake. Urinary excretion of prostasin in rats that were infused with aldosterone likwise increased by $\sim 4$-fold when compared with the vehicle-infused rats. Finally, urinary excretion of prostasin in patients with primary aldosteronism was substantially increased when compared with normal patients. Adrenalectomy reduced urinary prostasin excretion to control levels, whereas urinary prostasin levels were not altered in patients undergoing surgery for other reasons. In patients with primary aldosteronism, reduction in the urinary excretion of prostasin correlated with the increase in the urinary $\mathrm{Na} / \mathrm{K}$ ratio. These findings, together with our previous report that prostasin activates the amiloride-sensitive $\mathrm{Na}$ currents through $\mathrm{ENaC}$, demonstrate that prostasin regulates $\mathrm{Na}$ balance in vivo by virtue of its heightened expression in the presence of aldosterone.

J. Clin. Invest. 109:401-408 (2002). DOI:10.1172/JCI200213229.

\section{Introduction}

Aldosterone is the primary hormone that regulates $\mathrm{Na}$ balance, extracellular fluid volume, and blood pressure (1-3). Aldosterone increases the rate of $\mathrm{Na}$ reabsorption across epithelia at the distal nephron, the distal colon, and the ducts of exocrine glands by increasing $\mathrm{Na}$ transport through the epithelial $\mathrm{Na}$ channel $(\mathrm{ENaC})$, one of the principal physiologic targets of aldosterone $(4,5)$. Regulation of $\mathrm{ENaC}$ by aldosterone has been extensively studied in the A6 renal cell line (6). In $\mathrm{A} 6$ cells, the effect of aldosterone on $\mathrm{ENaC}$ is characterized by a three-phase response: (a) a latent period, lasting 45 minutes; (b) an early response, lasting about 3 hours, in which $\mathrm{Na}$ transport increases and the transepithelial electrical resistance falls; and (c) a late response, lasting 12 to 24 hours, during which $\mathrm{Na}$ transport further increases while transepithelial resistance does not change significantly. The early and late effects of aldosterone appear to be mediated by transcriptional mechanisms because actinomycin D fully inhibits both actions (7). In addition to transcriptional regulation, May et al. reported that aldosterone increases the rate of de novo synthesis of $\mathrm{ENaC} \alpha$ subunit 60 minutes after treatment, raising the possibility that aldosterone may exert its early phase action on $\mathrm{ENaC}$ through translational mechanisms (6). Further- more, Weisz et al. reported the importance of aldosterone-induced trafficking and turnover of individual $\mathrm{ENaC}$ subunits in $\mathrm{A} 6$ cells (8). They demonstrated that long-term treatment with aldosterone stimulated $\mathrm{Na}$ influx by the selective insertion of $\beta \mathrm{ENaC}$ at the apical membrane of A6 cells.

In 1997, a novel mechanism by which serine proteases regulate $\mathrm{ENaC}$ activity was identified. Vallet et al. cloned a new serine protease, $\mathrm{xCAP}-1$, from A6 cells $(9,10)$. They showed that coexpression of XCAP- 1 and $\mathrm{ENaC}$ in Xenopus oocytes increased the amiloride-sensitive Na current $\left(I_{\mathrm{Na}}\right)$ by two- to threefold. Chraibi et al. also reported that low concentrations of trypsin $(2 \mu \mathrm{g} / \mathrm{ml})$ increased $I_{\mathrm{Na}}$ by two- to fivefold in oocytes expressing $\mathrm{ENaC}$ (11). The precise molecular mechanisms of activation of $\mathrm{ENaC}$ by serine proteases are not fully understood. Vuagniaux et al. isolated a cDNA clone of mCAP-1 from a mouse cortical collecting duct (CCD) cell line and suggested that CAP-1 is an orthologous gene for prostasin (12). They also demonstrated that mCAP-1/prostasin activates $\mathrm{ENaC}$ when expressed in oocytes. Recently, we isolated a cDNA clone of rat prostasin, a serine protease that is expressed in the same epithelial tissues as $\mathrm{ENaC}$, from the rat kidney (13). We demonstrated that prostasin is expressed in rat kidney collecting ducts and that coexpression of rat prostasin with rat $\mathrm{ENaC}$ increased $I_{\mathrm{Na}}$ 
two- to threefold in Xenopus oocytes. We proposed that prostasin might play an important role in $\mathrm{Na}$ handling in the kidney by activating $\mathrm{ENaC}$. However, regulation of prostasin mRNA, protein, or activity by physiologic stimuli, or under pathophysiologic conditions, is not yet established. Therefore, we investigated the regulation of prostasin expression by aldosterone because aldosterone is one of the principal regulators of $\mathrm{Na}$ reabsorption in the distal nephron.

We found that treatment of a mouse CCD cell line with aldosterone increased the secretion of prostasin protein into culture media and that aldosterone stimulated ${ }^{22} \mathrm{Na}$ uptake by increasing prostasin expression. We also found that increased aldosterone levels in rats markedly increased the urinary excretion of prostasin. Furthermore, we demonstrated that the urinary excretion of prostasin was substantially increased in patients with primary aldosteronism and that adrenalectomy significantly reduced urinary prostasin excretion. These results indicate that prostasin is an important physiologic regulator of $\mathrm{Na}$ handling in the kidney.

\section{Methods}

Cloning of mouse prostasin cDNA. A partial cDNA fragment of mouse prostasin was obtained by PCR with two degenerate primers that correspond to amino acid sequences of human prostasin as described previously (13-15). A first-strand cDNA was synthesized from mouse kidney total RNA by the oligo (dT) primer method and amplified by these primers. The amplified DNA fragment was subcloned into pGEM-T Easy vector (Promega Corp., Madison, Wisconsin, USA) and sequenced. The $5^{\prime}$ and $3^{\prime}$ ends of mouse prostasin cDNA was cloned by the $5^{\prime}$ and $3^{\prime}$ rapid amplification of cDNA ends (RACE) system (Life Technologies Inc., Rockville, Maryland, USA), following the manufacturer's protocol. Briefly, mouse kidney total RNA was reverse-transcribed with antisense primer 5A-m 1 (5'-CCCAACTCACAATGCCTGCCAA-3') for the $5^{\prime}$-RACE reaction. The cDNA that was generated was amplified by nested antisense primers, 5A-m2 (5'-ACCCTGGCAGGCATCCTTGC$\left.3^{\prime}\right)$ and 5A-m3 (5'-CGGCTGATGAGTGGTACCTC-3'), sequentially with the abridged anchor primer and the abridged universal amplification primer (AUAP). For the $3^{\prime}$ RACE reaction, total RNA was reverse-transcribed and amplified by nested PCR with two sense primers, 3S-m1 (5'-GAGGTACCACTCATCAGCCG-3') and 3S-m2 ( $5^{\prime}$-GGCCCACTCTCTTGTCCCAT- $\left.3^{\prime}\right)$, and the AUAP primer. Both $5^{\prime}$ and $3^{\prime}$ RACE products were subcloned into pGEM-T Easy vector and sequenced. A full-length mouse prostasin cDNA was obtained by ligating the $5^{\prime}$ cDNA end, the partial cDNA fragment, and the $3^{\prime}$ cDNA end. The nucleotide sequence (mouse prostasin cDNA) reported in this paper has been submitted to the Genbank/EMBL/DDBJ Data Bank with accession number AB038244.

Cell culture. M-1 cells, an SV40-transformed mouse CCD cell line, were obtained from the American Type Culture Collection (Rockville, Maryland, USA). Cells were maintained in DMEM/Ham's F-12 (1:1) mixture (Life Technologies Inc.) supplemented with 5\% FBS and $100 \mathrm{nM}$ dexamethasone in a humidified incubator at $37^{\circ} \mathrm{C}$ and $5 \% \mathrm{CO}_{2}$. Experiments were performed when cells were confluent. Serum and dexamethasone were removed 48 hours before experiments. All studies described in this paper were performed on cells between the 5 th and 20th passages.

Northern blot analysis. Total RNA from M-1 cells grown in 10-cm plastic dishes under experimental conditions was isolated by using an RNeasy kit (QIAGEN GmbH, Hilden, Germany). Total RNA $(20 \mu \mathrm{g})$ of each sample was resolved on agarose-formaldehyde gels and transferred onto nylon membranes. A full-length cDNA of mouse prostasin and rat $\beta$-actin was individually labeled with $\left[\alpha-{ }^{32} \mathrm{P}\right] \mathrm{dCTP}$, and probes were hybridized with the membranes as described previously (13).

Preparation of proteins and TCA precipitation. After incubation under experimental conditions, culture medium (10 ml/10-cm dish) was collected and centrifuged at $1,200 \mathrm{~g}$ to pellet cell debris. Total protein in the culture media was precipitated by trichloroacetic acid (TCA) (final concentration: 15\%). The samples were centrifuged at $12,000 \mathrm{~g}$, and the pellets were washed three times with ice-cold $80 \%$ acetone. The precipitated proteins were dried and solubilized at $100^{\circ} \mathrm{C}$ for 5 minutes in $1 \times \mathrm{TCA}$ buffer (200 mM unbuffered Tris, 1\% SDS, 10\% glycerol, $1 \% \beta$-mercaptoethanol). For preparation of membrane and cytosolic fractions of M-1 cells, confluent M-1 cells were washed twice in PBS, scraped into lysis buffer $(25$ $\mathrm{mM}$ Tris- $\mathrm{HCl}, \mathrm{pH} 7.5,4 \mu \mathrm{g} / \mathrm{ml}$ aprotinin, $4 \mu \mathrm{g} / \mathrm{ml}$ leupeptin, $1 \mathrm{mM}$ PMSF, and $4 \mu \mathrm{g} / \mathrm{ml}$ pepstatin $\mathrm{A}$ ), and lysed in a glass Dounce homogenizer. The homogenate was centrifuged at $800 \mathrm{~g}$ to remove nuclei, and the supernatant was centrifuged at $12,000 \mathrm{~g}$ to separate the membrane and cytosolic fractions. The membrane fraction was then dissolved in RIPA buffer $(50 \mathrm{mM}$ Tris- $\mathrm{HCl}, \mathrm{pH}$ 7.5, $150 \mathrm{mM} \mathrm{NaCl}, 0.1 \%$ SDS, $0.5 \%$ deoxycholate, $1 \%$ $\mathrm{vol} / \mathrm{vol}$ Triton-X 100, $2 \mathrm{mM}$ EDTA, $4 \mu \mathrm{g} / \mathrm{ml}$ aprotinin, 4 $\mu \mathrm{g} / \mathrm{ml}$ leupeptin, $1 \mathrm{mM}$ PMSF, and $4 \mu \mathrm{g} / \mathrm{ml}$ pepstatin $\mathrm{A})$. All these procedures were performed at $4^{\circ} \mathrm{C}$.

Immunoblotting. Samples were resolved on $12 \%$ SDSPAGE and transferred onto nitrocellulose filters. After blocking with $5 \mathrm{~g} / \mathrm{dl}$ nonfat dry milk, the blots were probed with a polyclonal $\mathrm{Ab}$ against prostasin (15) in Tris-buffered saline with $0.05 \%$ Tween- 20 for 1 hour, followed by a secondary Ab (goat anti-rabbit IgG conjugated with horseradish peroxidase) for 1 hour at room temperature. Bands were visualized using chemiluminescence substrate (ECL; Amersham Pharmacia Biotech, Amersham, United Kingdom) followed by exposure to $\mathrm{x}$-ray film. The band densities were quantitated by densitometry (Densitograph 4.0; ATTO Co., Tokyo, Japan).

${ }^{22} \mathrm{Na}$ influx studies. The activities of $\mathrm{ENaC}$ in $\mathrm{M}-1$ cells were determined by measurement of amiloride-sensitive ${ }^{22} \mathrm{Na}$ uptake (16). Preliminary experiments determined that amiloride-sensitive uptake of ${ }^{22} \mathrm{Na}$ was linear for up to 15 minutes. After incubation under experimental con- 
ditions, cells on six-well dishes were rinsed twice and preincubated for 15 minutes at $37^{\circ} \mathrm{C}$ in a Na-free solution composed of $137 \mathrm{mM} \mathrm{N}$-methylglucamine (NMDG), $5.4 \mathrm{mM} \mathrm{KCl}, 1.2 \mathrm{mM} \mathrm{MgSO}_{4}, 2.8 \mathrm{mM} \mathrm{CaCl}_{2}$, and $15 \mathrm{mM}$ HEPES ( $\mathrm{pH}$ 7.4). At the end of the preincubation, the Na-free solution was replaced by the uptake solution composed of $14 \mathrm{mM} \mathrm{NaCl}, 35 \mathrm{mM} \mathrm{KCl}, 96 \mathrm{mM}$ NMDG, and $20 \mathrm{mM}$ HEPES ( $\mathrm{pH} 7.4$ ) containing $1 \mathrm{mM}$ ouabain and $1.5 \mu \mathrm{Ci} / \mathrm{ml}$ of ${ }^{22} \mathrm{NaCl}$ (specific activity: 748 $\mu \mathrm{Ci} / \mathrm{mg} \mathrm{Na}$; New England Nuclear, Boston, Massachusetts, USA) in the presence or absence of $1 \mathrm{mM}$ amiloride. After a 5-minute incubation, uptake was stopped by washing the cells four times with $1 \mathrm{ml} /$ well of an ice-cold solution containing $120 \mathrm{mM} \mathrm{NMDG}$ and $20 \mathrm{mM}$ HEPES ( $\mathrm{pH} 7.4$ ). The cells were then solubilized in $0.5 \%$ Triton X-100. Tracer activities were measured in a gamma scintillation counter. The amount of protein per well was measured using the BCA kit (Pierce Chemical Co., Rockford, Illinois, USA). All assays were performed in duplicate. ENaC activity was determined as the difference between ${ }^{22} \mathrm{Na}$ uptake in the presence or absence of amiloride. The results were normalized for protein concentration and expressed as percentage of control.

Aldosterone infusion studies. Experiments were conducted in male Sprague-Dawley rats $(160 \sim 170 \mathrm{~g})$ from Charles River Laboratories (Wilmington, Massachusetts, USA). Rats were anesthetized with pentobarbital sodium (Nembutal; Abbot Laboratories, North Chicago, Illinois, USA) before subcutaneous implantation of osmotic minipumps (model 2001; Alza Corp., Palo Alto, California, USA) that delivered $100 \mu \mathrm{g} / 100 \mathrm{~g}$ body weight aldosterone per day (17). Aldosterone (Sigma Chemical Co., St. Louis, Missouri, USA) was dissolved in DMSO and diluted with isotonic saline. Control rats received vehicle alone. All rats were kept in metabolic cages, and 24-hour urine collections were made. Urine samples, corrected for creatinine excretion, were concentrated by TCA precipitation, and the amount of prostasin was determined by immunoblotting as described above. Blood samples were obtained at the end of the experiments to measure plasma aldosterone, serum potassium, and serum bicarbonate concentrations. All animal procedures were approved by the institutional ethics committee.

Patients with primary aldosteronism. Three patients with primary aldosteronism and three patients undergoing surgery for other reasons with general anesthesia were enrolled in the study. Institutional approval was received from the Kumamoto University Human Subject Review Board, and written informed consent was obtained from each patient prior to the studies. All patients with primary aldosteronism were treated with adrenalectomy, and 24-hour urine collections were obtained before and after surgery. The prostasin excretion level in urine samples was determined by the same method as described above.

\section{Results}

Cloning of full-length mouse prostasin cDNA. To evaluate the level of prostasin mRNA expression in the M- 1 cell line by Northern blotting, we isolated a full-length prostasin cDNA from mouse kidney using RT-PCR, 5' and $3^{\prime}$ RACE methods. The prostasin cDNA encodes a 339-amino acid polypeptide, including a 29-amino acid signal peptide, a 15 -amino acid light chain, and a 295-amino acid heavy chain. The catalytic triad that is highly conserved among the serine proteases is also found in mouse prostasin ( $\mathrm{His}^{85}$, Asp ${ }^{134}$, and $\mathrm{Ser}^{238}$ ). Vuagniaux et al. proposed that mCAP-1, xCAP-1, and human prostasin are orthologous genes (12). Our cloning of mouse prostasin cDNA also revealed that mouse prostasin is identical to the mCAP-1 at the amino acid level.

Effect of aldosterone on prostasin expression in $M-1$ cells. Previously, we demonstrated that expression of prostasin stimulates ENaC in Xenopus oocytes (13). May et al. also reported that aldosterone increases $\mathrm{ENaC}$ activity as well as $\mathrm{ENaC}$ protein translation in A6 cells (6). These findings motivated us to study the effect of aldosterone on the expression of prostasin. We used M-1 cells to study the regulation of prostasin by aldosterone because both prostasin and $\mathrm{ENaC}$ are expressed in the CCD segment $(12,13,18)$ and aldosterone modulates $\mathrm{Na}$ transport in M-1 cells (19). We measured prostasin mRNA abundance in M-1 cells following aldosterone treatment. Figure 1 shows the time course of prostasin mRNA induction by aldosterone. Prostasin transcripts were readily detected under basal conditions. Aldosterone induced an increase in prostasin mRNA after 6 hours of stimulation. Maximum induction occurred at 24 hours (1.9-fold \pm 0.2 -fold), and elevated mRNA levels were still present for up to 48 hours.

We then determined the distribution of prostasin protein between M-1 cell membranes and cytosol. Based on its predicted secondary structure, prostasin is presumed to be a secreted and/or a glycosylphosphatidylinositol-anchored protein, so we also determined if it was present in cell culture medium. Proteins in the membrane and cytosolic fractions of M-1 cells and culture media were precipitated by TCA and subjected to immunoblotting. As shown in Figure 2a, the antiprostasin $\mathrm{Ab}$ detected a single band of $40 \mathrm{kDa}$ only in the culture media under reducing conditions. The band was barely detectable in either the membrane or cytosolic fractions (left panel). The $40-\mathrm{kDa}$ band was completely blocked by the incubation of $\mathrm{Ab}$ with the synthetic prostasin peptide used for immunization, demonstrating the specificity of the immunodetection (Figure 2a, right panel). We could not detect prostasin protein in the membrane or cytosolic fractions even when we immunoblotted $80 \mu \mathrm{g}$ of protein. While prostasin protein was shown to be secreted when synthesized in the prostate (15), recent findings also indicated that it can assume a membrane-anchored form via glycosylphosphatidylinositol in prostate epithelial cells that naturally express prostasin (20). In the M-1 cells, it is possible that the distribution of the membrane-anchored versus the secreted prostasin protein for the total pool of prostasin protein synthesized is 


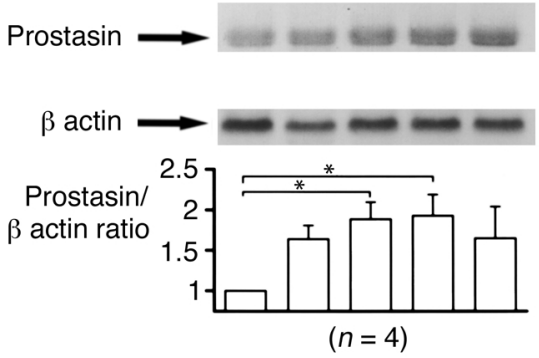

different from that in the prostate cells. We speculate that prostasin is synthesized as a membrane protein that is quickly cleaved by some mechanism and released into the extracellular medium. Consequently, in subsequent studies, we analyzed expression of prostasin protein in the culture media of M-1 cells. Figure $2 \mathrm{~b}$ shows that treatment with aldosterone increased the expression of prostasin protein by 3.5fold \pm 0.6 -fold and 3.3-fold \pm 0.3 -fold when compared with the controls during 24-hour and 48-hour incubations. This stimulatory effect of aldosterone on prostasin protein expression was dose dependent over the range $0-10^{-6} \mathrm{M}$ (Figure $3 \mathrm{c}$ ). Even after treatment with aldosterone, we could not detect prostasin protein in either membrane or cytosolic fractions (data not shown). These findings demonstrate that aldosterone stimulates expression of prostasin at the levels of mRNA as well as protein in M-1 cells.

Effect of aprotinin on aldosterone-induced ${ }^{22} \mathrm{Na}$ uptake in M-1 cells. To determine if the aldosterone-induced increase in prostasin protein abundance in $\mathrm{M}-1$ cells indeed has a role in activating $\mathrm{ENaC}$, we measured amiloride-sensitive ${ }^{22} \mathrm{Na}$ uptake. $\mathrm{M}-1$ cells were treated for 24 hours with $1 \mu \mathrm{M}$ aldosterone or vehicle in the

\section{Figure 2}

Effect of aldosterone on the expression of prostasin protein in $\mathrm{M}-1$ cells. (a) Cellular distribution of prostasin protein in M-1 cells. Forty micrograms of membrane and cytosolic proteins as well as $3 \mathrm{ml}$ of TCA-precipitated culture medium from $\mathrm{M}-1$ cells were subjected to SDS-PAGE. Blots were probed with the antiprostasin $A b$ and with $A b$ preadsorbed with the immunizing peptide. Prostasin was detected as a 40-kDa band in the culture medium only. (b) Effect of aldosterone on the expression of prostasin protein in M-1 cells. M-1 cells were treated with $1 \mu \mathrm{M}$ aldosterone or vehicle for 24 and 48 hours. Proteins in the culture medium were TCA precipitated and subjected to SDSPAGE. Treatment with $1 \mu \mathrm{M}$ aldosterone increased prostasin protein expression by 3.5 -fold \pm 0 .6-fold (for 24 hours) and 3.3-fold \pm 0.3 fold (for 48 hours) when compared with the corresponding controls. This blot is representative of five separate experiments. Aldo, aldosterone; cont, control. Values are mean $\pm \operatorname{SEM}(n=5)$. (c) Dose dependence of aldosterone effect on prostasin. $M-1$ cells were treated with increasing concentrations of aldosterone $\left(0,10^{-8}, 10^{-7}\right.$, and $\left.10^{-6} \mathrm{M}\right)$ for 24 hours. The expression level of prostasin in the culture media was determined by immunoblotting. The stimulatory effect of aldosterone on prostasin protein expression was dose dependent over the range of $0-10^{-6} \mathrm{M}$. This blot is representative of five separate experiments. Values are mean $\pm \operatorname{SEM}(n=5) .{ }^{*} P<0.001,{ }^{*} P<0.02$.

\section{Figure 1}

Effect of aldosterone on the expression of prostasin mRNA in M-1 cells. M-1 cells, which were serum deprived for 48 hours, were treated with $1 \mu \mathrm{M}$ aldosterone and harvested at various time points $(0,6,12$, 24 , and 48 hours) for isolation of total RNA. Each lane contains $20 \mu \mathrm{g}$ of total RNA. The abundance of prostasin mRNA was normalized for $\beta$-actin (bottom). Aldosterone induced an increase in prostasin mRNA after 6 hours of stimulation. Maximum induction occurred at 24 hours (1.9-fold \pm 0.2 -fold increase), and this effect was observed for up to 48 hours. This blot is representative of four separate experiments. Values are mean $\pm \operatorname{SEM}(n=4) .{ }^{*} P<0.02$.

presence or absence of $28 \mu \mathrm{g} / \mathrm{ml}$ aprotinin, a potent prostasin inhibitor $\left(\mathrm{IC}_{50}\right.$ of aprotinin for prostasin is $11.7 \mathrm{ng} / \mathrm{ml})(15)$, and then amiloride-sensitive ${ }^{22} \mathrm{Na}$ uptake was measured. As shown in Figure 3a, treatment with aprotinin decreased the amiloride-sensitive ${ }^{22} \mathrm{Na}$ uptake by $25 \% \pm 9 \%$ under basal conditions. Nakhoul et al. reported that aprotinin reduced the $I_{\mathrm{sc}}$ in M-1 cells by $49 \% \pm 9 \%$ (19). The difference in the magnitude of the aprotinin-sensitive component in the basal Na current in M-1 cells could have resulted from the differences of the methods used. Aldosterone increased the ${ }^{22} \mathrm{Na}$ uptake by $189 \% \pm 25 \%$, and aprotinin significantly reduced the $\mathrm{Na}$ influx in aldosterone-treated cells. Interestingly, aprotinin-sensitive Na uptake was markedly increased by twofold in aldosterone-treated cells when compared with the control. Also, aldosterone increased the aprotinin-insensitive component. To address the question if sufficient
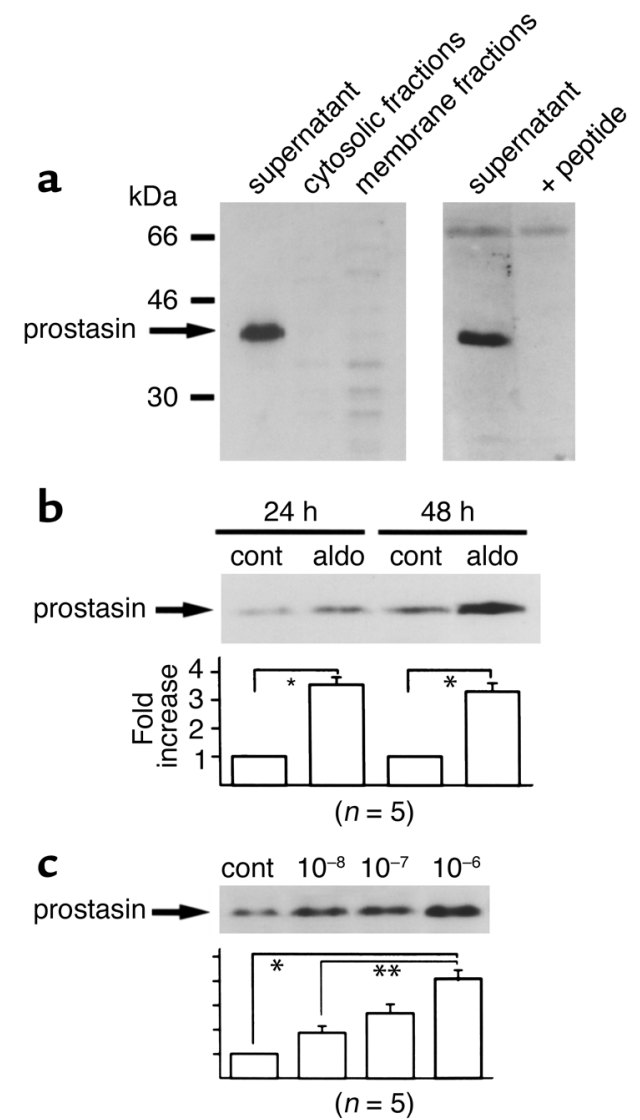


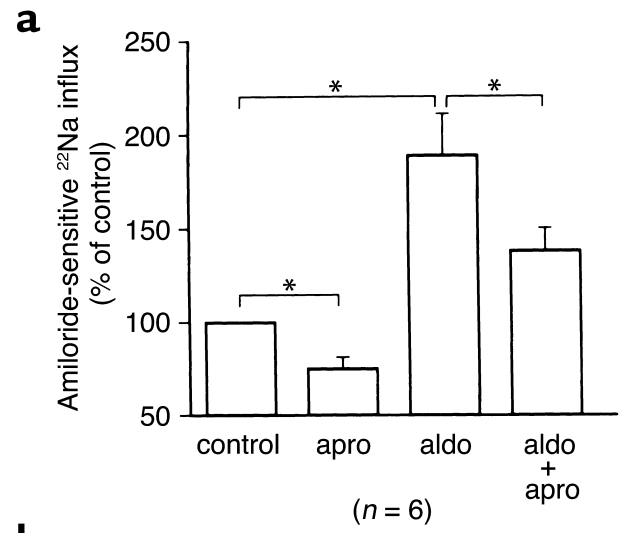

b

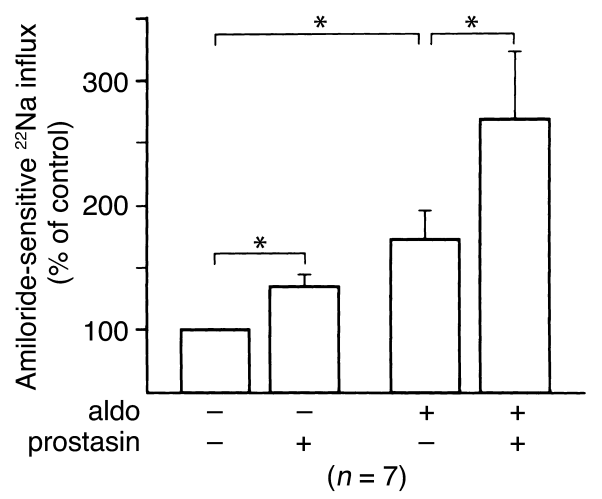

\section{Figure 3}

Role of prostasin in the aldosterone-induced increase in ${ }^{22} \mathrm{Na}$ uptake in M-1 cells. (a) Effect of aprotinin on aldosterone-induced ${ }^{22} \mathrm{Na}$ uptake in $\mathrm{M}-1$ cells.M-1 cells were treated with $1 \mu \mathrm{M}$ aldosterone or vehicle for 24 hours in the presence or absence of $28 \mu \mathrm{g} / \mathrm{ml}$ aprotinin. Amiloridesensitive ${ }^{22} \mathrm{Na}$ uptake was determined in the presence of $1 \mathrm{mM}$ amiloride and $1 \mathrm{mM}$ ouabain. Treatment with aprotinin partially inhibited the basal $\mathrm{Na}$ influx as well as the aldosterone-induced $\mathrm{Na}$ influx. Aldosterone significantly increased the aprotinin-sensitive Na uptake twofold. Apro, aprotinin. Values are mean $\pm \operatorname{SEM}(n=6)$. (b) Effect of recombinant prostasin on aldosterone-induced ${ }^{22} \mathrm{Na}$ uptake in $\mathrm{M}-1$ cells. M-1 cells were treated with $1 \mu \mathrm{M}$ aldosterone or vehicle for 24 hours, then cells were treated with $2 \mu \mathrm{g} / \mathrm{ml}$ of recombinant prostasin. Amiloride-sensitive ${ }^{22} \mathrm{Na}$ uptake was determined as described above. Treatment with recombinant prostasin further increased the basal $\mathrm{Na}$ influx as well as the aldosterone-induced $\mathrm{Na}$ influx (1.35-fold and 1.56 -fold, respectively). Values are mean $\pm \operatorname{SEM}(n=7) .{ }^{*} P<0.05$.

prostasin might be present in the culture media under basal conditions to activate $\mathrm{ENaC}$, and if an aldosterone-mediated increase in prostasin secretion into culture media might have a minimal effect on further enhancing $\mathrm{ENaC}$ activity, we treated $\mathrm{M}-1$ cells with purified recombinant prostasin (20) in the presence or absence of aldosterone and measured the amiloridesensitive ${ }^{22} \mathrm{Na}$ uptake. Figure $3 \mathrm{~b}$ shows that the addition of recombinant prostasin further increased the ${ }^{22} \mathrm{Na}$ uptake by 1.35 -fold in control cells and by 1.56 fold in aldosterone-treated cells, suggesting that $\mathrm{ENaC}$ expressed on the apical membrane of $\mathrm{M}-1$ cells are not fully activated by prostasin under basal conditions and that an aldosterone-induced increase in the prostasin abundance in the culture media has a definite role in the activation of $\mathrm{ENaC}$. These results, taken together with the findings that aldosterone increases prostasin protein expression in M-1 cells, demonstrate that M-1 cells have aprotinin-sensitive $\mathrm{Na}$ uptake under basal conditions that is probably due to prostasin expression and that aldosterone substantially increases the prostasin-dependent Na uptake by increasing prostasin protein abundance. Furthermore, these findings strongly support our hypothesis that aldosteroneinduced increase in prostasin protein has a key role in the aldosterone-induced activation of $\mathrm{ENaC}$.

Effect of amiloride on aldosterone-induced prostasin expression in M-1 cells. Aldosterone activates Na transport in M-1 cells (19) and distal tubules of other species (2) through activation of $\mathrm{ENaC}$. Prostasin expression could be increased by mechanisms that are a consequence of activation of $\mathrm{ENaC}$, such as an increase in the intracellular $\mathrm{Na}$ concentration. To determine whether an increase in prostasin expression is secondary to an event following the activation of $\mathrm{ENaC}$ by aldosterone, we studied the effect of amiloride, a potent $\mathrm{ENaC}$ inhibitor, on the aldosterone-induced increase in prostasin expression in the cell culture media. M-1 cells were preincubated with $5 \mu \mathrm{M}$ amiloride for 30 minutes, and then aldosterone (final $1 \mu \mathrm{M})$ was added to the media in the presence of amiloride. Twenty-four hours after incubation, medium was collected and subjected to immunoblotting. As shown in Figure 4, amiloride treatment had no effect on either basal or aldosterone-induced prostasin protein expression. These results suggest that the induction of prostasin by aldosterone is not mediated by an amiloride-sensitive mechanism that is secondary to $\mathrm{ENaC}$ activation. We then studied the effect of prostasin on the amiloride sensitivity of $\mathrm{ENaC}$. The $K i_{\text {amil }}$ of $\mathrm{ENaC}$ in the absence of prostasin $(0.10 \pm 0.006$ $\mu \mathrm{M} ; n=12)$ did not significantly differ from the $K i_{\text {amil }}$ in the presence of prostasin $(0.094 \pm 0.005 \mu \mathrm{M} ; n=14)$.

Aldosterone-infusion studies. To study the stimulatory effect of aldosterone on prostasin expression in vivo, we infused rats with aldosterone through subcuta-

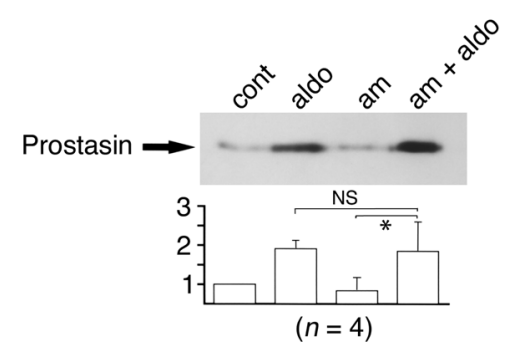

\section{Figure 4}

Effect of amiloride on aldosterone-induced expression of prostasin protein in M-1 cells. M-1 cells were treated with $1 \mu \mathrm{M}$ aldosterone or vehicle in the presence or absence of $5 \mu \mathrm{M}$ amiloride for 24 hours. Prostasin protein abundance was determined by immunoblotting. Treatment of M-1 cells with amiloride had no effect on the secretion of prostasin in the culture media (aldosterone: 1.9 -fold \pm 0.2 -fold, aldosterone + amiloride: 1.8 -fold \pm 0.7 -fold, not significant). This figure is representative of four separate experiments. Am, amiloride. Values are mean $\pm \operatorname{SEM}(n=4)$. NS, not significant; ${ }^{*} P<0.02$. 


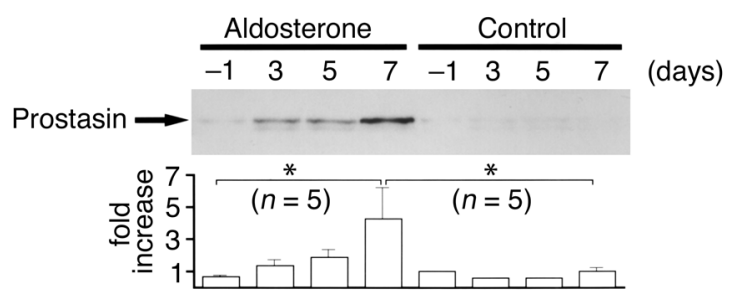

Figure 5

Effect of aldosterone infusion on prostasin excretion in the urine. Immunoblot showing the effect of aldosterone infusion $(100 \mu \mathrm{g} / 100$ g body weight/day) for 7 days on the abundance of prostasin excreted into rat urine. Urine samples that are equivalent to $80 \mu \mathrm{g}$ creatinine excretion were TCA precipitated, and urinary prostasin excretion was determined by immunoblotting. Aldosterone infusion resulted in a substantial increase in prostasin excretion into the urine. The effect of aldosterone was time dependent, and maximum induction was observed at day 7 (4.3-fold \pm 2 .0-fold increase over control). This figure is representative of five separate experiments. Values are mean $\pm \operatorname{SEM}(n=5) .{ }^{*} P<0.004$.

neously implanted osmotic minipumps for 7 days. Plasma aldosterone levels were significantly increased in aldosterone-infused rats (control: $134 \pm 23 \mathrm{pg} / \mathrm{ml}$, $n=5$, and aldosterone: $3,425 \pm 354 \mathrm{pg} / \mathrm{ml}, n=5$, $P<0.05)$. The aldosterone-treated rats also exhibited hypertension (control: $111 \pm 5 \mathrm{mmHg}, n=5$, and aldosterone: $127 \pm 2 \mathrm{mmHg}, n=5, P<0.05)$, hypokalemia (control: $5.0 \pm 0.2 \mathrm{mEq} / \mathrm{l}, n=5$, and aldosterone: $3.3 \pm 0.8 \mathrm{mEq} / 1, n=5, P<0.05)$, and metabolic alkalosis (control: $27.0 \mathrm{HCO}_{3} \pm 1.9 \mathrm{mEq} / \mathrm{l}$, $n=5$, and aldosterone: $\mathrm{HCO}_{3} 41.3 \pm 1.7 \mathrm{mEq} / 1, n=5$, $P<0.05) 7$ days after pump implantation. There was not any significant difference in the body weight between control rats and aldosterone-treated rats (control: $220 \pm 6 \mathrm{~g}, n=5$, and aldosterone: $215 \pm 5 \mathrm{~g}$, $n=5, P=$ not significant). We could not detect prostasin expression by immunoblotting membrane or cytosolic fractions of rat kidney cortex and medulla with or without aldosterone infusion (data not shown). However, we easily detected prostasin in rat urine under basal conditions. These data suggest that prostasin is released from the apical membrane of kidney tubules by some mechanisms in rats as well as in the mouse CCD cell line. As shown in Figure 5, aldosterone infusion resulted in a substantial increase in prostasin excretion into the urine. The effect of aldosterone was time dependent, and the maximum induction was observed at day 7 (4.3-fold \pm 2.0 -fold increase over control). These findings indicate that aldosterone induces prostasin expression in the kidney in whole animals as well as in cultured cells and that it may play an important role in the impaired $\mathrm{Na}$ handling in patients with hyperaldosteronism.

Urinary prostasin levels in patients with primary aldosteronism. To determine whether aldosterone increases prostasin protein expression in humans, we measured urinary prostasin protein expression in patients with primary aldosteronism before and after adrenalectomy. The diagnosis of an aldosterone-secreting adrenal adenoma was made on the basis of measurement of plasma renin activity and plasma aldosterone levels and by radiologic examinations, including computed tomography and magnetic resonance imaging scans. Patient profiles, plasma renin activities, plasma aldosterone concentration (PAC), and serum potassium levels of the patients are shown in Table 1 . To study urinary prostasin excretion, 24hour urine collections were obtained before and 7 days after adrenalectomy. Figure 6 a shows the results of Western blot analysis of urinary prostasin excretion before and after adrenalectomy from patient number 1. Adrenalectomy resulted in a marked decrease in urinary prostasin protein abundance. PAC was also reduced to the normal range after the operation (Table 1). Interestingly, the urinary $\mathrm{Na} / \mathrm{K}$ ratio correlated with the expression level of prostasin, suggesting that aldosterone-induced prostasin plays a role in activation of $\mathrm{ENaC}$ (Figure 6a). Patients with high PAC level (numbers 1-3) had substantially higher urinary prostasin excretion when compared with normal PAC level patients (numbers 4-6) (Figure 6b). In all three patients with primary aldosteronism, adrenalectomy resulted in a significant decrease in the urinary prostasin excretion, while no change in urinary prostasin excretion was observed in the three patients with normal PAC levels (Figure 6b). These results indicate that prostasin is regulated by aldosterone in humans as well as in rats.

Table 1

Clinical profiles of the patients with primary aldosteronism and other diseases

\begin{tabular}{|c|c|c|c|c|c|c|c|c|}
\hline Patients & Sex & $\begin{array}{c}\text { Age } \\
\text { (years old) }\end{array}$ & $\begin{array}{l}\text { Height } \\
(\mathrm{cm})\end{array}$ & $\begin{array}{l}\text { BW } \\
\text { (kg) }\end{array}$ & $\begin{array}{c}\text { PRA } \\
\text { (ng/ml/h) } \\
\text { before/after }\end{array}$ & $\begin{array}{c}\mathrm{PAC} \\
(\mathrm{pg} / \mathrm{ml}) \\
\text { before/after }\end{array}$ & $\begin{array}{c}\mathrm{p}-\mathrm{K} \\
(\mathrm{mEq} / \mathrm{l})\end{array}$ & Diseases \\
\hline 1 & Male & 22 & 175 & 69.6 & $<0.1 / 0.1$ & $330 / 50$ & 2.8 & PA \\
\hline 2 & Female & 51 & 155 & 51.1 & $<0.1 / 0.2$ & $189 / 51$ & 3.2 & PA \\
\hline 3 & Female & 43 & 160 & 57.6 & $<0.1 / 0.1$ & $778 / 34$ & 2.0 & PA \\
\hline 4 & Male & 26 & 171 & 89.0 & $0.6 / 0.5$ & $80 / 58$ & 4.2 & Achalasia \\
\hline 5 & Female & 51 & 151 & 45.0 & $0.5 / 0.2$ & $91 / 49$ & 3.9 & PHP \\
\hline 6 & Male & 37 & 178 & 92.5 & $1.8 / 1.3$ & $94 / 110$ & 4.2 & Cholelithiasis \\
\hline
\end{tabular}

Values are mean \pm SEM. Plasma renin activities PRA and PAC were measured before and 7 days after the operation in each patient. BW, body weight; $\mathrm{P}-\mathrm{K}$, serum potassium; PA, primary aldosteronism; PHP, primary hyperparathyroidism, PRA, plasma renin activities. 
a

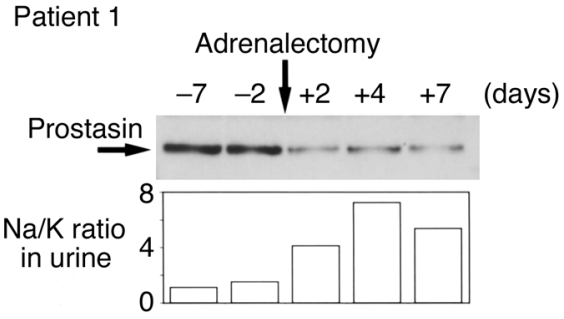

b

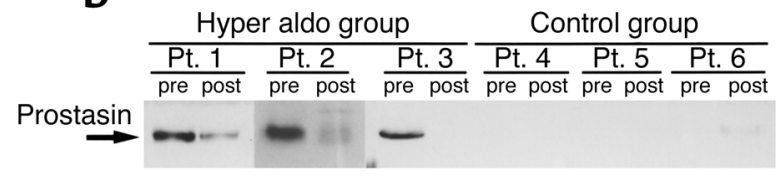

\begin{abstract}
Figure 6
Urinary prostasin levels in patients with primary aldosteronism and control patients. (a) Time course of urinary prostasin expression in patients with primary aldosteronism (patient 1 ) before and after the adrenalectomy. Sample volumes were adjusted to be equivalent to $750 \mu \mathrm{g}$ creatinine excretion, and urinary excretion of prostasin was determined by the immunoblotting. Urinary $\mathrm{Na} / \mathrm{K}$ ratio is shown at the bottom. (b) Urinary prostasin excretion in two other independent patients with primary aldosteronism (patients 2 and 3 ) and in three other independent patients with normal PAC level who had the surgery for other reasons (patients 4, 5, and 6). Twenty-four-hour urine collections were made before and 7 days after surgery. The urinary excretion of prostasin was determined by immunoblotting as described above. Pt, patient.
\end{abstract}

\section{Discussion}

Serine proteases such as CAP-1, trypsin, and chymotrypsin have been shown to stimulate $I_{\mathrm{Na}}$ in Xenopus oocytes expressing $\mathrm{ENaC}$, although the precise mechanisms of activation are not known (10-12). We cloned a rat prostasin cDNA and demonstrated that expression of rat prostasin increased the $\mathrm{Na}$ current through $\mathrm{ENaC}(13)$. Prostasin is expressed in epithelial tissues that are known to be the sites of amiloride-sensitive transepithelial Na transport. Therefore, we hypothesized that prostasin may play an important role in $\mathrm{Na}$ handling by the kidney through the activation of $\mathrm{ENaC}$. In the present studies, we addressed the question of whether aldosterone, a major natriferic hormone that increases $\mathrm{Na}$ uptake in the distal nephron by activation of $\mathrm{ENaC}$, could regulate the expression of prostasin in mammals. We showed that aldosterone stimulates $\mathrm{Na}$ uptake by increasing the expression of prostasin mRNA and protein in cultured mouse CCD cells. We also showed that urinary excretion of prostasin is increased in aldosterone-infused rats and in patients with primary aldosteronism.

Regulation of prostasin by aldosterone. In the study presented here, we showed that aldosterone induces a twofold increase in prostasin mRNA in M-1 cells. Because we have not yet measured the rate of transcription of this gene, we do not know whether the increased abundance of mRNA is mediated by a direct transcriptional effect and/or by an effect on mRNA turnover. The stimulatory effect of aldosterone on the accumulation of prostasin protein in the culture media or urine was proportional to the effect on mRNA abundance. Aldosterone significantly induced prostasin excretion in rat and human urine by approximately twofold. In the current study we have not addressed the question of whether aldosterone could regulate the assembly of prostasin in the endoplasmic reticulum, its transport to the plasma membrane, its release from the plasma membrane, and the stability of the released protein in the culture media or urine; each step could be separate sites of hormonal regulation.

Possible involvement of prostasin in aldosterone-induced $\mathrm{Na}$ absorption. Here we demonstrated that treatment of M-1 cells increases aprotinin-sensitive, further, prostasin-sensitive, $\mathrm{Na}$ uptake by increasing the prostasin protein abundance. Until this report, there was no direct evidence showing that serine proteases are involved in $\mathrm{Na}$ reabsorption in the distal nephron. However, data in several papers support the concept that serine proteases may play a key role in Na uptake in the kidney (9-13). Nakhoul et al. demonstrated that aprotinin added to the luminal side of $\mathrm{M}-1$ cells induces a $50 \%$ decrease in the $I_{\mathrm{sc}}$, suggesting that serine proteases such as prostasin could stimulate $\mathrm{ENaC}$ activity since aprotinin is a potent inhibitor of prostasin activity (19). More recently, Masilamani et al. reported that aldosterone infusion in rats resulted in a molecular weight shift of $\gamma \mathrm{ENaC}$ from 85 $\mathrm{kDa}$ to $70 \mathrm{kDa}$ (21). They speculated that proteolytic cleavage of the $\gamma \mathrm{ENaC}$ by serine proteases such as CAP-1 might be responsible for this phenomenon. Since prostasin is expressed in the collecting ducts and is excreted into urine, it may participate in the molecular weight shift of $\gamma \mathrm{ENaC}$ and subsequent activation of $\mathrm{ENaC}$ in mammals. Nafamostat mesilate (NM), a synthetic serine protease inhibitor, inhibits various serine proteases including trypsin, thrombin, activated factor $\mathrm{X}$, and activated complement. Although NM has been shown to be effective in the treatment of pancreatitis and disseminated intravascular coagulation, it is associated with hyponatremia and hyperkalemia in some cases (22). Muto et al. reported that perfusion of rabbit CCD with NM inhibited $I_{\mathrm{Na}}$, resulting in inhibition of potassium secretion $(23,24)$. They suggested that hyponatremia and/or hyperkalemia associated with NM treatment could be caused in part by inhibition of amiloride-sensitive Na conductance. This finding also implies physiologic involvement of serine proteases such as prostasin in Na handling in renal tubules.

Aldosterone stimulates $\mathrm{Na}$ reabsorption by multiple actions on multiple proteins involved in $\mathrm{Na}$ transport or its regulation. Aldosterone stimulates the transcription of $\mathrm{ENaC}$ in the kidney and increases the channel number at the apical membrane of the collecting duct, leading to an enhanced $\mathrm{Na}$ reabsorption in the distal nephron segment. Sgk, a serine/threonine kinase that activates electrogenic $\mathrm{Na}$ transport by increasing the number of $\mathrm{Na}$ channels $(\mathrm{ENaC})$ at the cell surface, is also an aldosterone-induced protein and may play a key role in the aldosterone-mediated 
regulation of $\mathrm{Na}$ absorption (25). Our current study suggests an additional mechanism by which aldosterone could stimulate $\mathrm{Na}$ transport through $\mathrm{ENaC}$ by way of increasing the expression of prostasin in the kidney. Our results provide a new insight into the regulation of distal nephron $\mathrm{Na}$ transport and pathogenesis of hypertension and provide the rationale for development of new therapeutic agents for hypertension and Na-retaining states.

\section{Acknowledgments}

We thank Shizuka Iida (Kurume University School of Medicine) and Junnosuke Inoue (Jikei Hospital) for sharing the urine samples of the primary aldosteronism patients. This work was supported by the Grants-in-Aid for Scientific Research from the Ministry of Education, Science and Culture in Japan (11770599 and 13770602 to K. Kitamura and 10671000, 11470219, and 11877177 to K. Tomita), The Salt Science Research Foundation (to K. Tomita), and Department of Defense Prostate Cancer Research Program Grants (DAMD 17-98-1-8590 and DAMD 17-02-1-0032 to K.X. Chai).

1. Barbry, P., and Lazdunski, M. 1996. Structure and regulation of the amiloride-sensitive epithelial sodium channel. Ion Channels. 4:115-167.

2. Garty, H., and Palmer, L.G. 1997. Epithelial sodium channels: function, structure, and regulation. Physiol. Rev. 77:359-396.

3. Funder, J.W. 1993. Aldosterone action. Annu. Rev. Physiol. 55:115-130.

4. Rossier, B.C. 1997. 1996 Homer Smith Award Lecture. Cum grano salis: the epithelial sodium channel and the control of blood pressure. J. Am. Soc. Nephrol. 8:980-992.

5. Verrey, F. 1999. Early aldosterone action: toward filling the gap between transcription and transport. Am. J. Physiol. 277:F319-F327.

6. May, A., Puoti, A., Gaeggeler, H.P., Horisberger, J.D., and Rossier, B.C. 1997. Early effect of aldosterone on the rate of synthesis of the epithelial sodium channel $\alpha$ subunit in A6 renal cells. J. Am. Soc. Nephrol. 8:1813-1822.

7. Verry, F., and Beron, J. 1996. Activation and supply of channels and pumps by aldosterone. News Physiol. Sci. 11:126-133.

8. Weisz, O.A., Wang, J.M., Edinger, R.S., and Johnson, J.P. 2000. Noncoordinate regulation of endogenous epithelial sodium channel $(\mathrm{ENaC})$ subunit expression at the apical membrane of A6 cells in response to various transporting conditions. J. Biol. Chem. 275:39886-39893.

9. Vallet, V., Horisberger, J.D., and Rossier, B.C. 1998. Epithelial sodium channel regulatory proteins identified by functional expression cloning. Kidney Int. Suppl. 67:S109-S114.

10. Vallet, V., Chraibi, A., Gaeggeler, H.P., Horisberger, J.D., and Rossier, B.C. 1997. An epithelial serine protease activates the amiloride-sensitive sodium channel. Nature. 389:607-610.

11. Chraïbi, A., Vallet, V., Firsov, D., Hess, S.K., and Horisberger, J.D. 1998. Protease modulation of the activity of the epithelial sodium channel expressed in Xenopus oocytes. J. Gen. Physiol. 111:127-138.

12. Vuagniaux, G., et al. 2000. Activation of the amiloride-sensitive epithelial sodium channel by the serine protease mCAP1 expressed in a mouse cortical collecting duct cell line. J. Am. Soc. Nephrol. 11:828-834.

13. Adachi, M., et al. 2001. Activation of epithelial sodium channels by prostasin in Xenopus oocytes. J. Am. Soc. Nephrol. 12:1114-1121.

14. Yu, J.X., Chao, L., and Chao, J. 1995. Molecular cloning, tissue-specific expression, and cellular localization of human prostasin mRNA. J. Biol. Chem. 270:13483-13489.

15. Yu, J.X., Chao, L., and Chao, J. 1994. Prostasin is a novel human serine proteinase from seminal fluid. Purification, tissue distribution, and localization in prostate gland. J. Biol. Chem. 269:18843-18848.

16. Folkesson, H.G., et al. 1998. Upregulation of alveolar epithelial fluid transport after subacute lung injury in rats from bleomycin. Am. J. Physiol. 275:L478-L490.

17. Kim, G.H., et al. 1998. The thiazide-sensitive $\mathrm{Na}-\mathrm{Cl}$ cotransporter is an aldosterone-induced protein. Proc. Natl. Acad. Sci. USA. 95:14552-14557.

18. Duc, C., Farman, N., Canessa, C.M., Bonvalet, J.P., and Rossier, B.C. 1994. Cell-specific expression of epithelial sodium channel $\alpha, \beta$, and $\gamma$ subunits in aldosterone-responsive epithelia from the rat: localization by in situ hybridization and immunocytochemistry. J. Cell Biol. 127:1907-1921.

19. Nakhoul, N.L., Hering-Smith, K.S., Gambala, C.T., and Hamm, L.L. 1998. Regulation of sodium transport in M-1 cells. Am. J. Physiol. 275:F998-F1007.

20. Chen, L.M., et al. 2001. Prostasin is a glycosylphosphatidylinositolanchored active serine protease. J. Biol. Chem. 276:21434-21442.

21. Masilamani, S., Kim, G.H., Mitchell, C., Wade, J.B., and Knepper, M.A. 1999. Aldosterone-mediated regulation of $\mathrm{ENaC} \alpha, \beta$, and $\gamma$ subunit proteins in rat kidney. J. Clin. Invest. 104:R19-R23.

22. Kitagawa, H., Chang, H., and Fujita, T. 1995. Hyperkalemia due to Nafamostat mesilate. New Engl. J. Med. 332:687.

23. Muto, S., Imai, M., and Asano, Y. 1993. Effect of nafamostat mesilate on $\mathrm{Na}^{+}$and $\mathrm{K}^{+}$transport properties in the rabbit cortical collecting duct. Br. J. Pharmacol. 109:673-678.

24. Muto, S., Imai, M., and Asano, Y. 1994. Mechanisms of the hyperkalaemia caused by nafamostat mesilate: effects of its two metabolites on $\mathrm{Na}^{+}$and $\mathrm{K}^{+}$transport properties in the rabbit cortical collecting duct. Br. J. Pharmacol. 111:173-178.

25. Chen, S.Y., et al. 1999. Epithelial sodium channel regulated by aldosterone-induced protein sgk. Proc. Natl. Acad. Sci. USA. 96:2514-2519. 